\title{
RAPD and Other PCR-based Analyses of Plant Genomes Using DNA Extracted from Small Leaf Disks
}

\author{
Jean-Marc Deragon and Benoit S. Landry \\ Agriculture Canada, St-Jean-sur-Richelieu, Québec, Canada, J3B 3E6
}

\begin{abstract}
A nondestructive, early DNA diagnostic system to implement marker-assisted selection in plant breeding programs has been developed. The main components of the system are a rapid and simple DNA microextraction method and fast DNA polymorphism analyses based on site-specific or arbitrary DNA amplification. A small disk $(5 \mathrm{~mm}$ diameter) is collected from one cotyledon or the first leaf of a young seedling using a common paper punch. Disruption of plant tissues is done by enzymatic digestion of cell walls. This ensures protection from sample-to-sample contamination and uniform DNA yield. DNA isolated from the resulting protoplasts is sufficient to perform a minimum of five and a maximum of $20 \mathrm{PCR}$ reactions/sample. Total DNA, nuclear DNA, and RNA can be analyzed selectively. The system has been tested successfully with eight major crops. Amplification products generated with DNA prepared with this quick procedure are equivalent to those obtained from CsCl-purified DNA. Up to 120 plants can be treated in 2 days and the procedure lends itself to automation. Potential applications in plant breeding will be discussed.
\end{abstract}

D NA markers linked to important agronomic traits rapidly are becoming part of plant breeding programs to help in the identification and selection of desirable genotypes in segregating populations..$^{(1-4)}$ However, the general utilization of this approach by breeders is hampered by technical inconveniences of the most widely used approach to detect DNA variations, DNA restriction fragment length polymorphism (RFLP) analyses. RFLP markerassisted selection is time consuming and requires access to a laboratory fully equipped for DNA manipulation, the use of radioactive isotopes, and personnel trained in molecular genetics. These requirements are generally not met by breeding teams. In addition, the RFLP technique requires large samples of plant tissue often available only from mature plants. This renders impossible early and nondestructive testing of young seedlings with RFLP markers.

Recently, a new type of genetic marker called random amplified polymorphic DNA (RAPD) has evolved from the PCR technology. ${ }^{(5-6)}$ RAPD markers are a promising tool for plant breeders because they do not have the technical inconveniences of RFLP markers, a very small amount of genomic DNA is required, and the analytical process is fast and relatively simple. Radioactive isotopes are not needed to visualize DNA polymorphisms and only modest laboratory equipment and personnel training are required. Although RAPD markers are generally inherited as dominant traits, the ease with which they can be used to construct saturated genetic maps allows the use of pairs of RAPD markers flanking a trait of interest for determining heterozygosity or homozygosity in a specific chromosomal area. ${ }^{(6)}$ Other analytic techniques based on site-specific $\mathrm{PCR}^{(7)}$ appear to have the potential to be used directly as a selection tool for desirable genotypes in breeding programs.

To apply this new technology, a plant DNA microextraction procedure suitable for RAPD and other PCR-based analysis had to be developed. The procedure should be very simple and successful for a broad range of crops so it can be used by a breeding laboratory not equipped for RFLP analysis. This paper describes a system that fulfills these criteria.

\section{MATERIALS AND METHODS Plant Materials}

We used the following species in these studies: Brassica napus cv. Westar and cv. Cresor (canola), Triticum aestivum cv. Messier (wheat), Avena sativa cv. Appalache (oat), Hordeum vulqare cv. Cadette (barley), Glycine soja cv. Maple arrow (soybean), Zea mays cv. Pioneer Hybrid 3737 (corn), Solanum tuberosum cv. Kennebec (potato), and Lycopersicum esculentum cv. Rutgers (tomato). The plants were either grown in a field or a greenhouse. Segregation analyses of RAPDs were done with 50 doubled haploid plants regenerated from the microspores of an $F_{1}$ hybrid (cv. Westar x cv. Cresor).

\section{Total DNA Microextraction}

Small $(0.5-\mathrm{cm})$ disks were collected from one cotyledon or from the first leaf of 2-week-old seedlings using a common paper punch. The paper punch was rinsed in a $95 \%$ ethanol 
solution between each leaf disk harvesting. The leaf disk was transferred into a $1.9-\mathrm{ml}$ tube containing $200 \mu \mathrm{l}$ of freshly prepared, filtered $(0.45 \mu \mathrm{m})$ digestion buffer [ $4 \%$ mannitol, $4 \%$ sorbitol, $10 \mathrm{mM} \mathrm{CaCl}, 10 \mathrm{mM}$ MES, $\mathrm{pH}$ $6.2,1 \%$ Macerase, and 5\% Cellulysin (Calbiochem Corp., LaJolla, CA)]. Up to 120 samples could be harvested in 1 hr. After a 30-min vacuum infiltration (25 $\mathrm{mmHg}$ ), the tubes were incubated in the dark at room temperature overnight (approximately $18 \mathrm{hr}$ ). After digestion, the tubes were then placed on ice and tipped gently to disperse the protoplasts. A slow centrifugation (5 min, $300 \mathrm{~g}$ at $4^{\circ} \mathrm{C}$ ) pelleted the protoplasts. They were then gently resuspended in $200 \mu \mathrm{l}$ of ice-cold washing buffer $(50 \mathrm{~mm}$ Tris- $\mathrm{HCl}, \mathrm{pH} 8.0$, $100 \mathrm{~mm}$ EDTA, and $5.5 \%$ sorbitol) and pelleted again under the same conditions. The protoplasts were resuspended at room temperature in $160 \mu \mathrm{l}$ of lysis buffer (50 mM Tris- $\mathrm{HCl}$, pH 8.0, $100 \mathrm{~mm}$ EDTA) and lysed by the addition of $40 \mu$ l of a $5 \%$ sodium sarkosyl solution followed by a 10 -min incubation at $60^{\circ} \mathrm{C}$. Cell debris could be removed optionally by a 15 -min centrifugation at $16,000 \mathrm{~g}$, but this step can be omitted without affecting the efficiency of the analysis system. DNA was precipitated by adding $90 \mu \mathrm{l}$ of a $10 \mathrm{M}$ ammonium acetate solution and $200 \mu \mathrm{l}$ of isopropanol to the mixture, and the tubes were left at room temperature for $10 \mathrm{~min}$. After a 15 -min centrifugation $(16,000 g)$, the DNA pellet was washed once with $70 \%$ ethanol, dried in vacuo, and resuspended in 50 $\mu l$ of TE buffer $(10 \mathrm{~mm}$ Tris- $\mathrm{HCl}, \mathrm{pH}$ 8.0, $1 \mathrm{mM}$ EDTA). Special attention should be paid to the DNA pellet because pellet loss after precipitation is the main reason for unsuccessful amplification. The tubes were placed $10 \mathrm{~min}$ at $55^{\circ} \mathrm{C}$ to help resuspend DNA and centrifuged for $2 \mathrm{~min}$ at $16,000 \mathrm{~g}$ to eliminate cell debris; the supernatant was transferred to a fresh tube.

This protocol yielded from 250 to $500 \mathrm{ng}$ of high-molecular-weight (>25 kb) total DNA, depending on the species, the age of the plants, and the source of tissue (cotyledon vs. leaf). DNA concentrations were determined by fluorescence in the presence of bisbenzimide (Hoechst dye 33258, Kodak) using a fluorescence spectrophoto- meter (model LS5, Perkin-Elmer; excitation, $365 \mathrm{~nm}$; emission, $460 \mathrm{~nm}$ ). This permitted precise determination of DNA concentration without interference from RNA or protein. RNA was optionally digested by adding $10 \mu \mathrm{g} / \mathrm{ml}$ of boiled RNase A (Sigma, St. Louis, $\mathrm{MO})$ to the resuspended DNA and by incubating for $10 \mathrm{~min}$ at $37^{\circ} \mathrm{C}$.

\section{Nuclear DNA Microextraction}

For the nuclear DNA microextraction, the same procedure as above was used up to and including the protoplast washing step. The protoplasts were instead resuspended in $200 \mu \mathrm{l}$ of ice-cold nuclei buffer $(50 \mathrm{~mm}$ Tris- $\mathrm{HCl}, \mathrm{pH} 8.0$, $100 \mathrm{mM}$ EDTA, 5.5\% sorbitol, and 0.5\% Triton $\mathrm{X}-100$ ) to lyse cells and organelles selectively but to protect nuclei. The mixture was placed on top of a cushion made of nuclei buffer containing $7.5 \%$ of sorbitol instead of $5.5 \%$. The tubes were then centrifuged for 5 $\min$ at $4^{\circ} \mathrm{C}(300 \mathrm{~g})$. The nuclei pellet was resuspended in nuclei buffer and this step was repeated twice. The nuclei were then lysed and DNA precipitated under the same conditions as for the total DNA extraction. This protocol yielded 100-250 ng of high-molecularweight nuclear DNA, sufficient for 5-10 RAPD reactions.

\section{Cesium Chloride-purified DNA}

Plant genomic DNAs were isolated as described by Bernatzky and Tanksley, ${ }^{(8)}$ with the exceptions that $\mathrm{Na}_{2} \cdot$ EDTA was increased to $70 \mathrm{~mm}$ and that $1 \% \beta$-mercaptoethanol was replaced with $20 \mathrm{~mm}$ sodium metabisulfite in the extraction buffer (R. Bernatzky, pers. comm.). DNA samples were then purified through a $\mathrm{CsCl} /$ ethidium bromide preparative ultracentrifugation $(75,000 \mathrm{rpm}$ for $4 \mathrm{hr}$ or $62,000 \mathrm{rpm}$ for $12 \mathrm{hr}$ in a Beckman $\mathrm{Vti} 80$ rotor).

\section{RAPD Reactions}

For the RAPD reactions, we used onetenth (total DNA) or one-fifth (nuclear DNA) of each microextraction in 10 $\mathrm{mm}$ Tris- $\mathrm{HCl}(\mathrm{pH} \mathrm{8.2)}, 50 \mathrm{~mm} \mathrm{KCl}, 2$ $\mathrm{mM} \mathrm{MgCl}_{2}, 0.02 \%$ gelatine, $200 \mu \mathrm{M}$ of each dNTP (Pharmacia) with $0.2 \mu \mathrm{M}$ of primer and 0.5 units of AmpliTaq (Cetus) in a final volume of $25 \mu$ l. The source of the polymerase is important for successful amplification. The mix- ture was covered with $25 \mu$ l of mineral oil and the tube was placed in a Hybaid thermal reactor programmed as follows: $30 \mathrm{sec}$ at $94^{\circ} \mathrm{C}$ (ramping 1.0) and $20^{\circ} \mathrm{C}$ for $10 \mathrm{~min}$ (ramping 2.0) for one cycle; $1 \mathrm{sec}$ at $50^{\circ} \mathrm{C}$ (ramping 5.0), $45 \mathrm{sec}$ at $72^{\circ} \mathrm{C}$ (ramping 1.0 ), $5 \mathrm{sec}$ at $94^{\circ} \mathrm{C}$ (ramping 1.0 ), and $30 \mathrm{sec}$ at $20^{\circ} \mathrm{C}$ (ramping 2.0) for 45 cycles; $5 \mathrm{~min}$ at $72^{\circ} \mathrm{C}$ (ramping 1.0) for one cycle. The ramping value represents the time in seconds required to increase or decrease the temperature by $1^{\circ} \mathrm{C}$. Temperature cycling conditions are specific to each model of thermal cycler apparatus. In addition, each unit was tested in four replicated experiments where a single large PCR reaction was separated in several tubes and loaded in each well. This was done to identify wells that systematically produce erratic results. RAPD primers were random 10-mers purchased from Operon Technologies Inc. (Alameda, CA, kit A to $G$ ) or acquired from the University of British Columbia as part of the UBC RAPD primer synthesis project (kit \#1). Table 1 lists the specific primers used in this study and their sequences.

\section{Sequence-specific Amplification Reactions}

The PCR reactions of site-specific amplifications were performed in the same buffer as above using primer atpB and primer rbcL (see Table 1). These primers were synthesized by the phosphoramidite method on a Gene Assembler (Pharmacia) and represent sequences 8617-8635 and 9714-9696 of the tobacco chloroplastic genome. ${ }^{(9)}$ The primers were designed to amplify the spacer region between chloroplastic genes atpB and $r b c L$. With Brassica napus DNA, this generated an amplification product of $2.5 \mathrm{~kb}$ (see Fig. 2). The Hybaid thermal reactor was programmed to perform the following cycles: $30 \mathrm{sec}$ at $94^{\circ} \mathrm{C}$ and $62^{\circ} \mathrm{C}$ for 10 $\mathrm{sec}$ for one cycle; $30 \mathrm{sec}$ at $72^{\circ} \mathrm{C}, 5 \mathrm{sec}$ at $94^{\circ} \mathrm{C}$, and $10 \mathrm{sec}$ at $62^{\circ} \mathrm{C}$ for 30 cycles; and $5 \mathrm{~min}$ at $72^{\circ} \mathrm{C}$ for one cycle. A "hot start" (addition of the enzyme at $62^{\circ} \mathrm{C}$ ) was used to minimize nonspecific amplification. ${ }^{(10)}$ The ramping option was turned off for sitespecific PCR amplifications to limit nonspecific products (heating and cooling at approximatively $2.0^{\circ} \mathrm{C} / \mathrm{sec}$ ). 
TABLE 1 List of the Primers Used in RAPD and PCR Reactions

\begin{tabular}{lll}
\hline Primers & Suppliers & Sequences \\
\hline E1 & Operon Tech. & CCCAAGGTCC \\
E2 & Operon Tech. & GGTGCGGGAA \\
E3 & Operon Tech. & CCAGATGCAC \\
E4 & Operon Tech. & GTGACATGCC \\
E6 & Operon Tech. & AAGACCCCTC \\
E11 & Operon Tech. & GAGTCTCAGG \\
B1 & Operon Tech. & GTTCGCTCC \\
B4 & Operon Tech. & GGACTGGAGT \\
B11 & Operon Tech. & GTAGACCCGT \\
B18 & Operon Tech. & CCACAGACGT \\
B20 & Operon Tech. & GGACCCTAC \\
U2 & University of British Columbia & CCTGGGCTTG \\
atpB & University of Montreal & ACCTTGAACTACCAGAGCG \\
rbcL & University of Montreal & GTTACTCGGAATGCTGCCA \\
\hline
\end{tabular}

\section{Electrophoresis Condition}

RAPD and PCR products were analyzed by mixed gel electrophoresis, $3.0 \%$ Nusieve:agarose (3:1), (FMC, Rockland $\mathrm{ME}$ ) for $3 \mathrm{hr}$ at $5 \mathrm{~V} / \mathrm{cm}$ in the TAE buffer system and stained with ethidium bromide prior to UV photography. ${ }^{(11)}$ One-half of the RAPD or PCR reaction was loaded on the gel.

\section{RESULTS AND DISCUSSION}

\section{The Microextraction Procedure}

Total DNA

Several plant DNA extraction procedures have been reported in the literature. ${ }^{(12-15)}$ However, none of these methods meets all requirements for efficient DNA diagnostic system: (1) quick and simple DNA extractions from a small amount of plant tissue; (2) capacity to process a large number of samples simultaneously; (3) uniform DNA yield; and (4) elimination of potential cross-contamination. We tested most of the published procedures and derivatives thereof and found two key steps that needed modification to meet these criteria; these were the techniques used for the disruption of plant tissues and for the elimination of plant cell contaminants. The first step is usually accomplished by partial mechanical grinding of individual samples, whereas the second relies on lengthy organic solvent extractions and selective precipitations. Therefore, we tried simpler and faster methods to solve these two problems.
DNA directly harvested after physical or alkaline disruption of plant tissues $^{(15-16)}$ was not able to support reproducible RAPD amplification either kilobase pairs) are shown on the right. because its yield was not sufficient and consistent, cross-contamination between samples could not be avoided or inhibitors of enzymatic activity copurified with it. It was found that digestion of the plant cell walls with a mixture of cellulase, hemicellulase, and pectinase followed by washing of the resulting protoplasts from the cell debris eliminated the inhibitory effect of components present in crude plant DNA preparations on the RAPD and PCR reactions and that no further purification step was necessary to obtain reproducible amplifications (see Fig. 1B,C). The DNA yield was very uniform between samples (Fig. 1A) and the procedure provides sufficient DNA to support 10-20 PCR reactions.

The success of this approach is mostly due to the uniform disruption of the plant tissues by the enzymatic digestion of the cell walls and to the elimination of a large portion of the

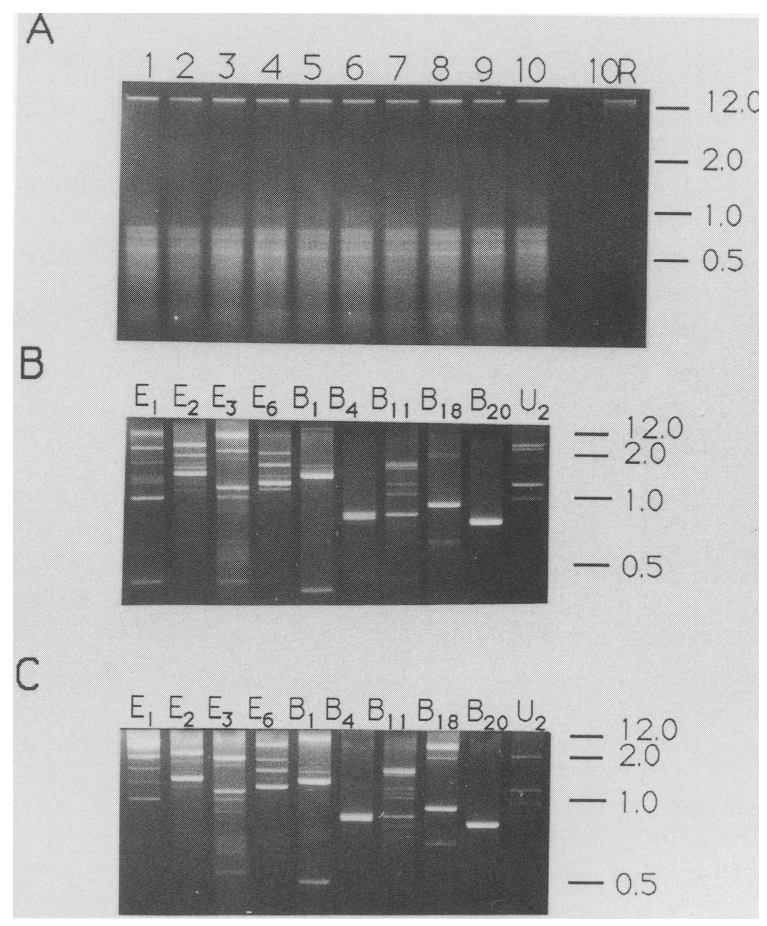

FIGURE 1 DNA yield uniformity and comparison of amplification products from our microextracted total DNA preparation with CsCl-purified total DNA. (A) Microextracted DNA preparations from 10 different doubled haploid plants (lanes $1-10$ ) regenerated from the microspores of a Brassica napus $\mathrm{F}_{1}$ hybrid. One sample, 10R (lane 12), was digested with RNase A $\left(10 \mu \mathrm{g} / \mathrm{ml}, 10 \mathrm{~min}\right.$ at $\left.37^{\circ} \mathrm{C}\right)$ prior to electrophoresis. In each lane, only one-tenth of the DNA microextracted from a leaf disk was loaded on the gel. $(B)$ Gel electrophoresis of RAPD products generated from the same microextracted preparations as shown in $A$ (one-tenth of the DNA preparation). The names of the primers used are indicated at the top of each lane (see Table 1 for the sequences). (C) Gel electrophoresis analysis of RAPD products obtained with $\mathrm{CsCl}$-purified DNA ( $25 \mathrm{ng} /$ reaction) of the same individuals as in $A$ and $B$. DNA sizes (in 


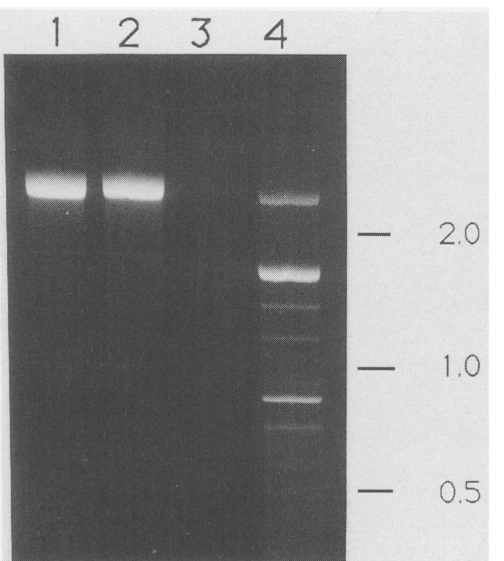

FIGURE 2 Test of nuclear DNA purity using chloroplast DNA site-specific PCR and RAPD reactions. Shown is gel electrophoresis of PCR products generated with primers atpB and rbcL (Table 1) using the following templates: (lane 1) $25 \mathrm{ng}$ of $\mathrm{CsCl}$-purified total DNA; (lane 2) one-tenth volume of microextracted total DNA and; (lane 3) onefifth volume of microextracted nuclear DNA. Primers atpB and rbcL are specific to the chloroplast genome and allow the amplification of a 2.5 -kb DNA sequence located between the two chloroplastic genes $a t p B$ and $r b c L$. Amplification was successful with the total DNA preparations (lanes 1 and 2). No amplification product was detected with the nuclear DNA preparation (lane 3), indicating an insufficient amount of chloroplast DNA template to support amplification. (Lane 4) Positive control RAPD products generated with primer E-3 using one-fifth volume of the DNA from the same microextracted nuclear DNA preparation used in lane 3; this indicates presence of sufficient nuclear DNA template in the DNA preparation to support normal amplification. DNA sizes (in kilobase pairs) are shown on the right.

contaminants before cell and nuclear lysis by subsequent washing of the protoplasts. Polysaccharides are major contaminants of enzymatic reactions, ${ }^{(12)}$ and, because they are located mainly in the cell walls and in the extracellular matrix, this procedure should eliminate most of them. In addition, the released protoplasts possibly leak several intracellular inhibitory components into the media during the enzymatic digestion due to the loss of selective permeability. These contaminants would also be eliminated during the washing of protoplasts.

RAPD and site-specific amplifications products generated from our DNA preparation and from $\mathrm{CsCl}-$ purified DNA of the same plants showed no significant differences in banding patterns (Figs. 1 and 2). The rate of successful amplification with microextracted preparations is identical to the one observed with $\mathrm{CsCl}$ purified DNA preparations (close to 95\%). This indicates that this extraction method is not altering the efficiency or accuracy of PCR reactions. This is not unusual because PCR-based methods are also known to work with crude preparations of human DNA. ${ }^{(17-18)}$ Figure 1 shows, for the same individual, small differences in the intensity of some bands or in the presence or absence of faint bands between our microextraction and $\mathrm{CsCl}$ purified DNAs. These small dissimilarities are not due to the use of more or less purified DNA, because they also occurred in different experiments with the same RAPD marker on the same sample of CsCl-purified DNA. Differences in the number of faint bands have also been observed with different $\mathrm{CsCl}$ preparations of the same individual. They are likely due to the high complexity of the RAPD amplification process, as indicated by Williams et al., ${ }^{(6)}$ and to differences in the average size of the DNA in different preparations. These small differences, however, do not affect the usefulness of the approach because only strong bands (such as the one presented in
Fig. 3) should be used in segregation analyses ${ }^{(6)}$; faint bands are generally not segregating in a Mendelian fashion.

\section{Nuclear DNA}

The presence of organelle DNA in the total DNA preparation is not a serious problem for segregation analyses and mapping studies because polymorphic markers generated by organelle DNA will show absolute maternal or paternal inheritance and will not segregate in a cross. The elimination of organelle DNA, however, could save time by ensuring the usefulness of each polymorphism detected between parental lines and by preventing unnecessary mapping attempts.

We adapted the total DNA microextraction procedure to obtain only nuclear DNA. The protoplast nuclei were separated from the cytoplasmic fraction by three consecutive centrifugations on a sorbitol cushion. We found that nuclear DNA can also support RAPD reaction with the same accuracy as CsCl-purified DNA, although one-fifth of the microextraction product instead of one-tenth was needed (Fig. 2). The discrepancy between total and nuclear DNA yields is likely due to DNA losses during the three additional steps of purifications. PCR amplification of a spacer region between two chloroplastic genes (atpB and $r b c L$ ) was

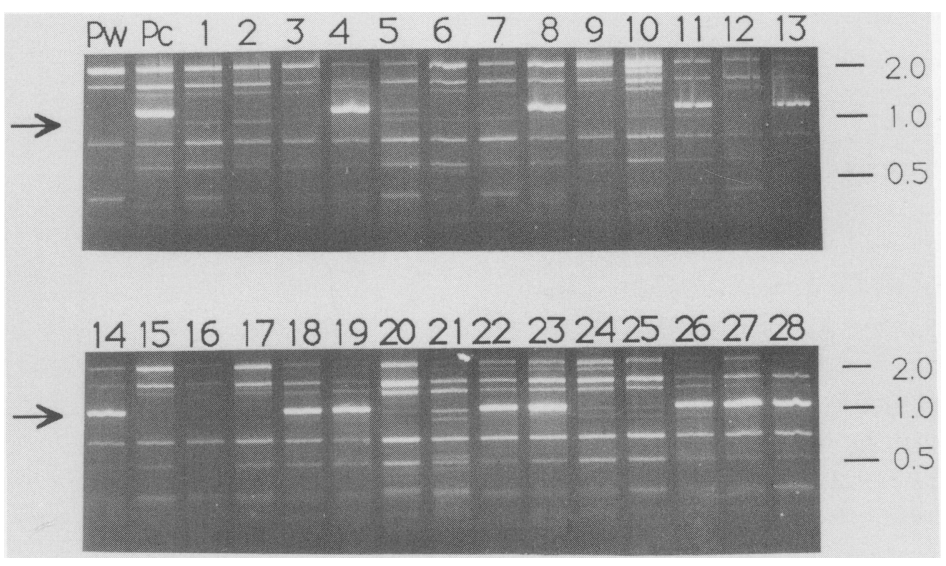

FICURE 3 Segregation of a RAPD marker (E11) in a Brassica napus population using microextracted total DNA. (Lane $P w$ ) cv. Westar; (lane $P c$ ) cv. Cresor. (Lanes 1-28) 28 doubled haploid plants regenerated from microspores of the $F_{1}$ hybrid (gametic segregation). The segregating DNA band is indicated by an arrow. The segregation ratio was $22: 28$ for all 50 doubled haploid plants analyzed. Only 28 plants are shown here. DNA sizes (in kilobase pairs) are shown on the right. 
only possible with total DNA preparations and not with nuclear DNA preparations (Fig. 2). This suggests that the amount of organelle DNA contaminants was negligible in our nuclear DNA preparation.

\section{Total RNA}

Treatment of the preparation with RNase confirmed that a large proportion of the nucleic acids purified by this procedure is RNA (Fig. 1A); and the presence of mostly intact RNAs in the preparation is indicated by the presence of ribosomal RNA bands (Fig. 1A). Our extraction conditions seem to provide sufficient protection against RNA degradation so that protocols based on the reverse transcription of RNA before PCR amplification ${ }^{(19-20)}$ could be tried. The presence of RNA sometimes affects the RAPD or PCR reaction.

\section{Segregation Analyses}

Segregation analyses of RAPD markers was performed with one of the crosses of Brassica napus (cv. Westar and cv. Cresor) currently being studied in our laboratory. The DNA was microextracted from seedlings of the two parents and from 50 doubled haploid seedlings produced from the microspores of one $F_{1}$ plant. Figure 3 shows a sample of the results obtained with primer E11, which produces a strong polymorphic DNA band between the two parents. The segregation ratio was 22:28 and not significantly different from the expected 1:1 ratio. These results also confirm that only strong bands can generally be used as reliable DNA markers. Other polymorphisms could be seen between the parental DNAs if faint bands were considered. These bands were either not segregating in the doubled haploid population or were segregating in a non-Mendelian fashion.

\section{DNA Microextraction Procedure with Other Major Crops}

To verify the general usefulness of our process, we tested it with seven other major crops-corn, wheat, barley, oat, soybean, tomato, and potato (Fig. 4). RAPD analyses could be performed successfully using the standard protocol with each of the crops tested. For each

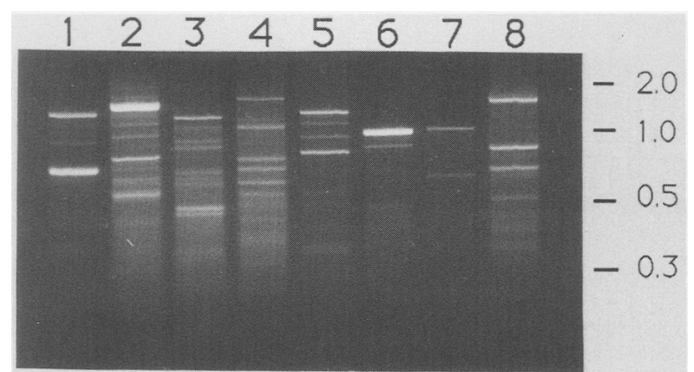

FIGURE 4 Demonstration of the universality of our analysis system using microextracted total DNA from eight major crops. (Lanes 1-8) Amplification products generated from DNA templates of: canola (lane 1), barley (lane 2, oat (lane 3), wheat (lane 4), soybean (lane 5), corn (lane 6) tomato (lane 7) potato (lane 8) (cultivar names are listed in the experimental procedures section). One-fifth of the DNA extracted from a leaf disk was used for soybean and tomato and one-tenth for the other crops. Results shown here are amplification products of one individual of each crop generated by primer E-2 except for lane 1 (canola) where it was accidentally replaced by primer E-4 on this gel. DNA sizes (in kilobase pairs) are shown on the right.

species, the extraction procedure was repeated 10 times using 10 leaf disks collected from the same individual; this experiment was done to monitor the uniformity of the amplification products, the repeatability of the procedure, and its universality. Three primers were tested on each DNA sample. All species gave similar rates of successful amplification (close to 95\%) and this rate was not different from the rate of successful amplification obtained with CsCl-purified DNA (not shown). However, soybean and tomato needed the addition of one-fifth of the microextracted total DNA (instead of one-tenth) to produce clear amplification signal reproducibly. This probably was due to the resilience of the leaf tissues to the enzymatic digestion. A more concentrated enzyme solution could provide a better digestion and increase DNA yield.

\section{CONCLUSION}

The fast-evolving PCR technology is establishing a foundation for rapid molecular testing of gene inheritance that will facilitate and accelerate plant breeding programs. Several components of a reliable DNA markerassisted selection system have to be put in place, including the development of a suitable plant DNA microextraction procedure. A plant microextraction procedure suitable for RAPD and other sequence-specific PCR-based techni- ques has been developed. This approach has many of the desirable features for routine use in molecular genetic testing. First, it is simple, reproducible, and less time consuming than full-scale DNA purification with equal efficiency in RAPD and other PCR reactions. Second, the procedure for plant tissue harvesting can be made very early in the life cycle of the plant, is nondestructive, and prevents crosscontamination; this allows the recovery of desirable genotypes after selection and further testing for other traits. Third, the protocol seems applicable for a broad spectrum of crops. Fourth, a relatively large number of RAPD reactions (5-20) can be done with DNA from a single leaf disk, allowing the testing of several markers. The number of testable DNA markers might be increased further if multiplex DNA amplification is performed. ${ }^{(21-22)}$ Finally, the procedure lends itself to automation. In addition to mapping and breeding applications, this system could be very useful for the rapid certification and quality control of hybrid seed production and for all projects based on PCR amplification of specific plant DNA fragments.

\section{ACKNOWLEDGMENTS}

We would like to thank Yves Dion of the Ministère de l'Agriculture et des Pêcheries du Québec for providing us with samples of wheat, oat, barley, and soybean. This work was partially sup- 
ported by research grants to B.S.L. from the Natural Sciences and Engineering Research Council of Canada and the National Strategy for Biotechnology. J.M.D. is a recipient of a Canadian Government Laboratory postdoctoral Fellowship.

\section{REFERENCES}

1. Beckmann, J.S. and M. Soller. 1986. Restriction fragment length polymorphisms and genetic improvement of agricultural species. Euphytica 35: 111-124.

2. Landry, B.S. and R.W. Michelmore. 1987. Methods and applications of restriction fragment length polymorphism analysis to plants. In Tailoring genes for crop improvement: An agricultural perspective (ed. G. Bruening, J. Harada and A. Hollaender), pp. 25-44. Plenum Press, New York.

3. Paterson, A.H., S. Damon, J.D. Hewitt, D. Zamir, H.D. Rabinowitch, S.E. Lincoln, E.S. Lander, and S.D. Tanksley. 1991. Mendelian factors underlying quantitative traits in tomato: Comparison across species, generations, and environments. Genetics 127: 181-197.

4. Tanksley, S.D., N.D. Young, A.H. Paterson, and M.W. Bonierbale. 1989. RFLP mapping in plant breeding: New tools for an old science. BioTechnology 7: 257-264.

5. Saiki, R.K., D.H. Gelfand, S. Stoffel, R. Scharf, R. Higuchi, G.T. Horn, K.B. Mullis, and H.A. Erlich. 1988. Primerdirected enzymatic amplification of DNA with a thermostable DNA polymerase. Science 239: 487-491.

6. Williams, J.G.K., A.R. Kubelik, K.J. Livak, J.A. Rafalski, and S.V. Tingey. 1990. DNA polymorphisms amplified by arbitrary primers are useful as genetic markers. Nucleic Acids Res. 18: 6531-6535.

7. Olson, M., L. Hood, C. Cantor, and D. Botstein. 1989. A common language for physical mapping of the human genome. Science 245: 14341435.

8. Bernatzky, R. and S.D. Tanksley. 1986. Genetics of actin-related sequences in tomato. Theor. Appl. Genet. 72: 314-321.

9. Shinazaki, K., H. Ohme, M. Tanaka, T. Wakasugi, N. Hayshida, T. Matsubayasha, N. Zaita, J. Chunwongse, J.
Obokata, K. Yamaguchi-Shinozaki, C. Ohto, K. Torazawa, B.Y. Meng, M. Sugita, H. Deno, T. Kamogashira, K. Yamada, J. Kusuda, F. Takaiwa, A. Kata, N. Tohdoh, H. Shimada, and M. Sugiura. 1986. The complete nucleotide sequence of the tobacco chloroplast genome: Its gene organization and expression. EMBO J. 5: 20432049.

10. Erlich, H.A., D. Gelfand, and J.J. Sninsky. 1991. Recent advances in the polymerase chain reaction. Science 252: 1643-1650.

11. Sambrook, J., E.F. Fristch, and T. Maniatis. 1989. Gel electrophoresis of DNA. In Molecular cloning; A laboratory manual, 2nd ed., pp. 6.3-6.62. Cold Spring Harbor Laboratory Press, Cold Spring Harbor, New York.

12. Draper, J. and R. Scott. 1988. The isolation of plant nucleic acids. In Plant genetic transformation and gene expression (ed. J. Draper, R. Scott, P. Armitage, and R.Walden), pp. 199236. Blackwell Scientific Publications, Oxford.

13. Clarke, B.C., L.B. Moran, and R. Appels. 1989. DNA analyses in wheat breeding. Genome 32: 334-339.

14. Webb, D.M. and S.J. Knapp. 1990. DNA extraction from a previously recalcitrant plant genus. Plant Mol. Biol. Rep. 8: 180-185.

15. Edwards, K., C. Johnstone, and C. Thompson. 1991. A simple and rapid method for the preparation of plant genomic DNA for PCR analysis. Nucleic Acids Res. 19: 1349.

16. Irvine, J.M., J.V. Oakes, C.K. Shewmaker, and A. Crossway. 1990. $A$ rapid screen for the detection of specific DNA sequences in plants. Gene Anal. Techn. Appl. 7: 25-31.

17. Ferre, F. and F. Garduno. 1989. Preparation of crude extract suitable for amplification of RNA by the polymerase chain reaction. Nucleic Acids Res. 17: 2141.

18. Mercier, B., C. Gaucher, O. Feugeas, and C. Mazurier. 1990. Direct PCR from whole blood, without DNA extraction. Nucleic Acids Res. 18: 5908.

19. Frohınan, M.A., M.K. Dush, and G.R. Martin. 1988. Rapid production of full-length cDNAs from rare transcripts: Amplification using a single gene-specific oligonucleotide primer. Proc. Natl. Acad. Sci. 85:
8998-9002.

20. Jepson, I., J. Bray, G. Jenkins, W. Schuch and K. Edwards. 1991. A rapid procedure for the construction of PCR CDNA libraries from small amounts of plant tissue. Plant Mol. Biol. Rep. 9: 131-138.

21. Chamberlain, J.S., R.A. Gibbs, J.E. Ranier, P.N. Nguyen, and C.T. Caskey. 1988. Deletion screening of the Duchenne muscular dystrophy locus via multiplex DNA amplification. Nucleic Acids Res. 16: 11141-11156.

22. Caetano-Anollés, G., B.J. Bassam, and P.M. Gresshoff. 1991. DNA amplification fingerprinting using very short arbitrary oligonucleotide primers. Bio/Technology 9: 553-556.

Received October 7, 1991; accepted in revised form November 15, 1991. 


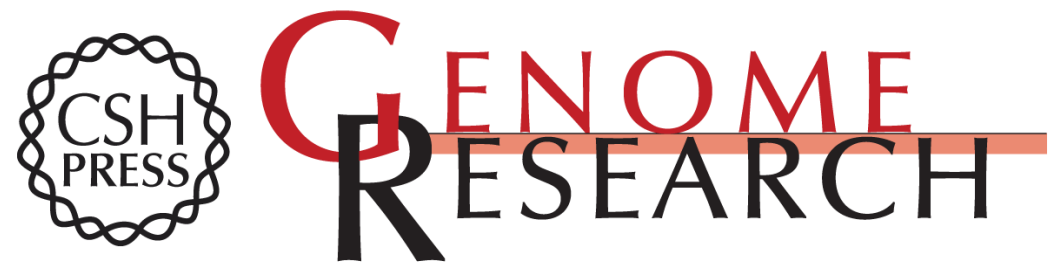

\section{RAPD and other PCR-based analyses of plant genomes using DNA extracted from small leaf disks.}

J M Deragon and B S Landry

Genome Res. 1992 1: 175-180

Access the most recent version at doi:10.1101/gr.1.3.175

References This article cites 19 articles, 5 of which can be accessed free at:

http://genome.cshlp.org/content/1/3/175.full.html\#ref-list-1

\section{License}

Email Alerting Receive free email alerts when new articles cite this article - sign up in the box at the Service top right corner of the article or click here.

\section{Affordable, Accurate Sequencing.}

To subscribe to Genome Research go to:

https://genome.cshlp.org/subscriptions 